\title{
Lamina-Specific Abnormalities of NMDA Receptor-Associated Postsynaptic Protein Transcripts in the Prefrontal Cortex in Schizophrenia and Bipolar Disorder
}

\author{
Monica Beneyto*,' and James H Meador-Woodruff' \\ 'Department of Psychiatry and Behavioral Neurobiology, University of Alabama at Birmingham, Birmingham, AL, USA
}

\begin{abstract}
The hypothesis of N-methyl-D-aspartate (NMDA) receptor hypofunction in schizophrenia was initially based on observations that blockade of the NMDA subtype of glutamate receptor by noncompetitive antagonists, such as phencyclidine and ketamine, can lead to clinical symptoms similar to those present in schizophrenia. Recently, glutamate has also been implicated in the pathophysiology of the mood disorders. As impaired NMDA receptor activity may be the result of a primary defect in the NMDA receptors themselves, or secondary to dysfunction in the protein complexes that mediate their signaling, we measured expression of both NMDA subunits and associated postsynaptic density (PSD) proteins (PSD95, neurofilament-light (NF-L), and SAP I02) transcripts in the dorsolateral prefrontal cortex in subjects with schizophrenia, bipolar disorder, major depression, and a comparison group using tissue from the Stanley Foundation Neuropathology Consortium. We found decreased NRI expression in all three illnesses, decreased NR2A in schizophrenia and major depression, and decreased NR2C in schizophrenia. We found no changes of NR2B or NR2D. Receptor autoradiography revealed no alterations in receptor binding in any of the illnesses, indicating no change in total receptor number, but taken with the subunit data suggests abnormal receptor stoichiometry. In the same subjects, PSD95 was unchanged in all three illnesses, while reduced NF-L expression was found in schizophrenia, especially in large cells of layer V. SAPI02 expression was reduced in bipolar disorder restricted to small cells of layer II and large cells of layer III in bipolar disorder. These alterations likely reflect altered signaling cascades associated with glutamate-mediated neurotransmission within specific cortical circuits in these psychiatric illnesses.

Neuropsychopharmacology (2008) 33, 2175-2 186; doi: I0.1038/sj.npp. I 301604; published online 2I November 2007
\end{abstract}

Keywords: glutamate; depression; in situ hybridization; receptor autoradiography; ionotropic receptors; postmortem

\section{INTRODUCTION}

The hypothesis of $N$-methyl-D-aspartate (NMDA) receptor hypofunction in schizophrenia was initially based on observations that blockade of the NMDA subtype of glutamate receptor by noncompetitive antagonists, such as phencyclidine and ketamine, can lead to clinical symptoms similar to those present in schizophrenia (Hertzmann et al, 1990). Subsequent studies have demonstrated that NMDA receptor antagonists can also lead to alterations in physiologic measures, including impaired prepulse inhibition (Duncan et al, 2004, 2006; Shoemaker et al, 2005; Moy et al, 2006) and increased subcortical dopamine release, which are observed in schizophrenia as well (Geyer and Braff, 1987; Grillon et al, 1992; McDowd et al, 1993; Braff et al, 1999).

\footnotetext{
*Correspondence: Dr M Beneyto, Department of Psychiatry, University of Pittsburgh, W 656 Biomedical Science Tower, 38 I I O'Hara Street, Pittsburgh, PA 15213, USA, Tel: + | 412383 5415, Fax: + I 412624 9910, E-mail: beneytom@upmc.edu Received 18 July 2006; revised 26 July 2007; accepted 2 I September 2007
}

Given these observations, the possibility of NMDA hypofunction in schizophrenia is an attractive and viable hypothesis. However, impaired NMDA receptor activity may be the result of a primary defect in the NMDA receptors themselves, or secondary to dysfunction in the postsynaptic proteins that mediate their signaling, leading to diminished NMDA receptor activity. Past studies on the expression of ionotropic glutamate receptors in psychiatric illnesses have focused almost exclusively on schizophrenia, and have concentrated on cortical and medial temporal lobe structures, generally revealing complex region- and receptor-specific abnormalities (McCullumsmith et al, 2004). Although previous reports have found alterations of glutamate receptor expression in schizophrenia, it is not well established if these receptors are also abnormal in the mood disorders, even though glutamate transmission abnormalities have been suggested for major depression (MDD) and bipolar disorder (BD) (Belsham, 2001a, b; Meador-Woodruff et al, 2001b; McCullumsmith and Meador-Woodruff, 2002; Molnar et al, 2003a; Du et al, 2004; Mueller and Meador-Woodruff, 2004; Woo et al, 2004).

NMDA glutamate receptors are combinations of six subunits, NR1, NR2A-D, and NR3, which form specific 
binding sites that provide substrates for the pharmacological regulation of the NMDA receptor. There is a primary binding site for glutamate, and separate polyamine and glycine (D-serine)-binding sites. Glutamate receptors and downstream signaling enzymes are targeted to a postsynaptic specialization of excitatory synapses known as the postsynaptic density (PSD). Apart from subunit composition of receptors, membrane insertion, functionality, and response to glutamate can be regulated by interactions with PSD proteins that can alter receptor sensitivity to glutamate and modulate signaling cascades by linking glutamate receptors to intracellular effector molecules. Proteins containing PDZ motifs play central roles in scaffolding NMDA receptors and linking them to signaling elements (Kennedy, 1997; Craven and Bredt, 1998; Hsueh and Sheng, 1998; Garner et al, 2000). The prototypical PDZ protein, PSD95, is a membrane-associated guanylate kinase (MAGUK) that contains three PDZ domains and associates with NMDA receptors. Two other MAGUKs, PSD-93 and synapse-associated protein SAP102, are also expressed in neurons throughout the brain. Some related proteins, such as neurofilament-light (NF-L), link NMDA receptors to the dendritic spine cytoskeleton.

In this study, we hypothesized that there are abnormalities of proteins associated with NMDA-mediated glutamate transmission in the dorsolateral prefrontal cortex (DLPFC) in schizophrenia. Accordingly, we assessed the expression of the NMDA subunits and three of the proteins implicated in their trafficking and signaling (PSD95, SAP102, and NFL) by in situ hybridization, as well as measuring receptor binding with MK801, ifenprodil, CGP39653, and MDL105519 in schizophrenia, MDD, BD, and a comparison group. We predicted that any changes in NMDA receptorrelated molecules in schizophrenia may be localized to specific cellular subpopulations in DLPFC, consistent with previous studies that found lamina- and cell-specific somatodendritic alterations in this illness that have been interpreted to suggest decreased synaptic connectivity of those cells. To determine the laminar and cellular specificity of any changes of the PSD proteins in schizophrenia and the mood disorders, cell-level in situ hybridization studies were also conducted.

\section{MATERIALS AND METHODS}

\section{Subjects and Tissue Preparation}

This study was done on post-mortem brains from 60 subjects obtained from the Stanley Foundation Neuropathology Consortium, consisting of 15 subjects each with diagnoses of schizophrenia, BD, MDD, and a comparison group (Torrey et al, 2000; Table 1). Serial sections (14 $\mu \mathrm{m}$ thick) were provided by the Stanley Foundation and stored at $-80^{\circ} \mathrm{C}$.

\section{In Situ Hybridization Histochemistry}

Riboprobes were synthesized from linearized plasmids containing subclones of the NMDA receptor subunits (NR1, NR2A-D), and the related intracellular proteins PSD95, SAP102, and NF-L (Table 2). Each NMDA subunit probe recognized all known isoforms and editing variants. Briefly, $10 \mu \mathrm{l}$ of $\left[{ }^{35} \mathrm{~S}\right]$-UTP was dried and $2.0 \mu \mathrm{l}$ $5 \times$ transcription buffer; $1.0 \mu \mathrm{l} 0.1 \mathrm{M}$ dithiothreitol (DTT); $1.0 \mu \mathrm{l}$ each of $10 \mathrm{mM}$ ATP, CTP, and GTP; $2.0 \mu \mathrm{l}$ linearized plasmid; $0.5 \mu \mathrm{l}$ RNase inhibitor; and $1.5 \mu \mathrm{l}$ T3, T7, or Sp6 RNA polymerase were mixed and incubated for $2 \mathrm{~h}$ at $37^{\circ} \mathrm{C}$. A total of $1.0 \mu$ l DNase (RNase-free) was then added, and the mixture was incubated for $15 \mathrm{~min}$ at room temperature. The reaction mixture was separated through spin columns

Table I Characterization of Subjects

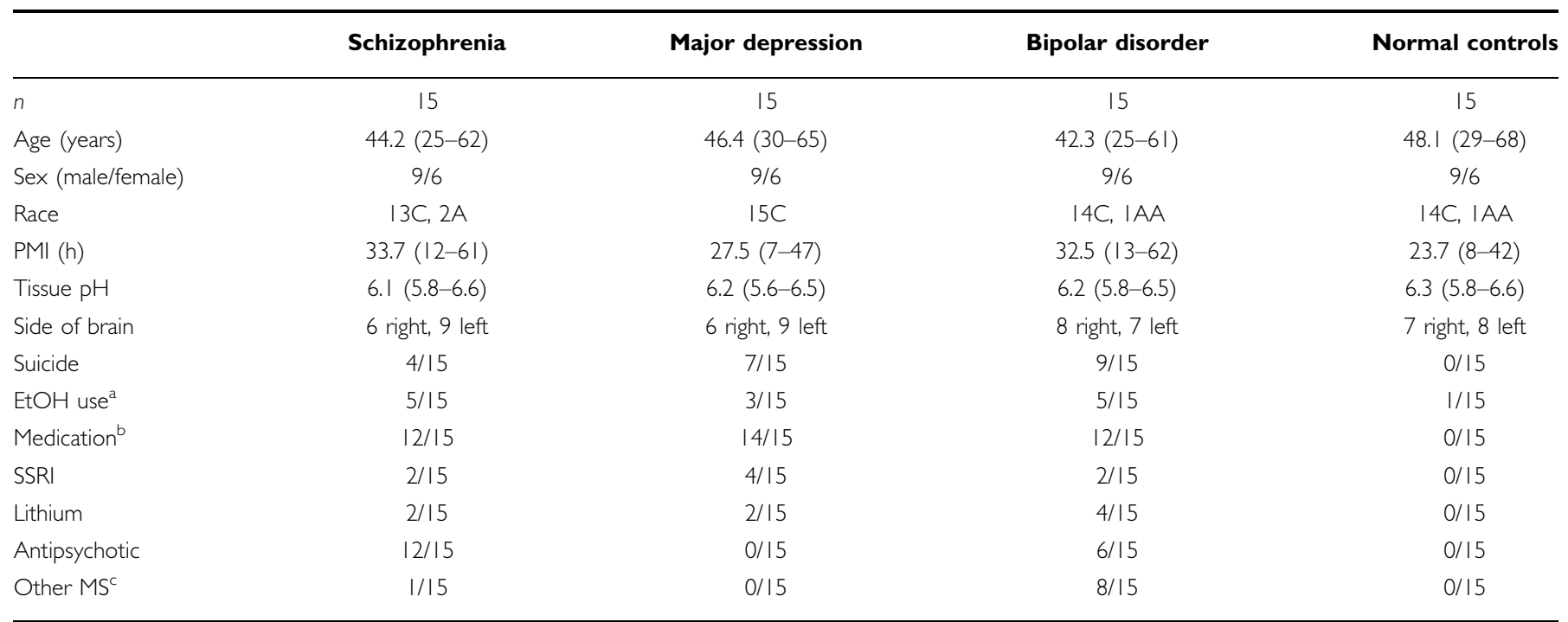

Abbreviations: C, Caucasian; AA, African-American; A, Asian; EtOH, ethanol; SSRI, selective serotonin reuptake inhibitor; PMI, post-mortem interval; MS, mood stabilizers.

a History of active $\mathrm{EtOH}$ abuse or dependence at the time of death.

${ }^{\mathrm{b}}$ Treatment with psychotropic medication within 6 weeks of the time of death.

${ }^{c}$ Carbamazepine and valproic acid. 
Table 2 Probe Characteristics

\begin{tabular}{llcc}
\hline Gene & $\begin{array}{l}\text { Accession } \\
\text { number }\end{array}$ & $\begin{array}{l}\text { Number of } \\
\text { bases (bp) }\end{array}$ & Region of gene \\
\hline NRI & U08263 & 460 & $923-1383$ \\
NR2A & DI32II & 668 & $815-1483$ \\
NR2B & NM_012574 & 808 & $1-808$ \\
NR2C & U08259 & 768 & $1-768$ \\
NR2D & U08260 & 783 & $118-901$ \\
PSD95 & U83192 & & $2113-2603$ \\
SAPI02 & NM_2II20 & 396 & $437-946$ \\
NF-L & NM_006I58 & 420 & $851-127 \mid$ \\
\hline
\end{tabular}

(Micro Bio-Spin P-30 Tris Chromatography Columns, BioRad Laboratories, Richmond, CA) and the purified fraction was eluted. DTT was added to each fraction to a final concentration of $0.01 \mathrm{M}$.

Two slides per subject for each probe were removed from $-80^{\circ} \mathrm{C}$ storage and placed in $4 \%$ (weight:vol) formaldehyde at room temperature for $1 \mathrm{~h}$. They were then rinsed in $2 \times$ standard saline citrate (SSC, $300 \mathrm{mM}$ sodium chloride, and $30 \mathrm{mM}$ sodium citrate, $\mathrm{pH} 7.2$ ) and subsequently treated with $0.1 \mathrm{M}$ triethanolamine $(\mathrm{pH} 8.0) /$ acetic anhydride $(400: 1)$ with stirring for $10 \mathrm{~min}$ at room temperature. The sections were rinsed in $2 \times$ SSC for $5 \mathrm{~min}$ and dehydrated in graded alcohols before air-drying. $\left[{ }^{35} \mathrm{~S}\right]-$ labeled probes were applied diluting $3-5 \times 10^{6}$ c.p.m. in $400 \mu \mathrm{l}$ per slide of hybridization buffer $(50 \%$ deionized formamide, $3 \times$ SSC, $1 \times$ Denhardt's solution $(0.02 \%$ polivinylpyrrolidone, $0.02 \%$ Ficoll, $0.02 \%$ bovine serum albu$\mathrm{min}), 2 \%$ yeast tRNA $(10 \mathrm{mg} / \mathrm{ml}), 50 \mathrm{mM}$ sodium phosphate ( $\mathrm{pH} 7.4$ ), and $10 \%$ dextran sulfate in sterile water). Slides were covered with glass coverslips, and placed in humid chambers containing an atmosphere saturated with $50 \%$ formamide at $55^{\circ} \mathrm{C}$ overnight.

After $16 \mathrm{~h}$ of hybridization, coverslips were removed and sections were washed three times in $2 \times \mathrm{SSC}$ at room temperature, immersed in RNAse A $(200 \mathrm{mg} / \mathrm{ml}$ in $10 \mathrm{mM}$ Tris, $0.5 \mathrm{M} \mathrm{NaCl}, \mathrm{pH} 8.0$ ) for $30 \mathrm{~min}$ at $37^{\circ} \mathrm{C}$, and then washed through descending concentrations of SSC to a final stringency of $0.5 \times \mathrm{SSC}$ at $55^{\circ} \mathrm{C}$ for $1 \mathrm{~h}$. Finally, the sections were dehydrated in graded ethanol washes, allowed to airdry, and placed in X-ray cassettes and exposed to Kodak Biomax MR film (Kodak, Rochester, NY) for 7-14 days.

For each probe, all subjects were run in the same experiment to eliminate interassay variability. Control slides were used to confirm the specificity of each riboprobe, running 'sense-strand'-labeled sections in parallel with those labeled with 'antisense-strand' probes.

\section{Receptor Autoradiography}

Receptor autoradiography was carried out under saturating conditions of ligand using assays that have been previously described in detail (Huettner and Bean, 1988; Ransom and Stec, 1988; Sills et al, 1991; Hashimoto et al, 1994; Baron et al, 1996; Siegel et al, 1996; White and Vogel, 1996; Healy et al, 1998; Healy and Meador-Woodruff, 1999; Ibrahim et al, 2000a, b). We examined multiple binding sites on the NMDA receptor, including the intrachannel site (visualized with $\left.\left[{ }^{3} \mathrm{H}\right] \mathrm{MK}-801\right)$, polyamine site $\left(\left[{ }^{3} \mathrm{H}\right]\right.$ ifenprodil), glutamate site $\left(\left[{ }^{3} \mathrm{H}\right]\right.$ CGP39653), and glycine coagonist site $\left(\left[{ }^{3} \mathrm{H}\right] \mathrm{MDL} 105,519\right)$. Slides from these studies were exposed to Amersham (Piscataway, NJ) $\left[{ }^{3} \mathrm{H}\right]$ Hyperfilm for 2 days $\left(\left[{ }^{3} \mathrm{H}\right]\right.$ MDL105,519), 3 days $\left(\left[{ }^{3} \mathrm{H}\right]\right.$ ifenprodil $), 1$ week $\left(\left[{ }^{3} \mathrm{H}\right]\right.$ MK-801), or 2 weeks ( $\left[{ }^{3} \mathrm{H}\right]$ CGP39653). Hyperfilm was developed in Kodak D-19 (4 min at $\left.19^{\circ} \mathrm{C}\right)$, agitated in $2 \%$ acetic acid (30 s), fixed in Kodak Rapid Fix ( $5 \mathrm{~min}$ ), washed under running water $(10 \mathrm{~min})$, and air-dried.

\section{Image Analysis}

Image analysis of in situ hybridization. Developed films were digitized and quantitated using NIH Image (v1.56) on a CCD-based imaging system. Each transcript showed a distinct pattern of laminar distribution across the cortical thickness, and gray scale values were obtained from bands with densities different from adjacent lamina (isodense bands). By overlapping images from thionin counterstaining of the same slides, we were able to correlate isodense bands (1-6) to cytoarchitectural cortical layers (I-VI). Isodense bands did not correspond exactly with traditionally defined cortical layers. Gray scale values from isodense bands were corrected for tissue background, and then converted to optical density (OD). OD values were converted to amount of radioactivity bound ( $\mathrm{nCi} / \mathrm{g}$ ) determined from calibrated $\left[{ }^{14} \mathrm{C}\right]$ microscale standards (Miller, 1991). Using the number of uridine residues contained in each molecule, the bound radioactivity value was converted to concentration of mRNA per isodense band, expressed as fmol/g of tissue. The values from two slides per subject were then averaged to obtain a single value for concentration of each mRNA in each isodense band.

Image analysis of receptor autoradiography. Developed films were digitized and quantitated using NIH Image software. For each cortical isodense band, gray scale values from the 'total' binding slides were corrected for nonspecific binding from an adjacent slide, and gray scale value was converted to OD. The final value was averaged from two slides per subject.

\section{Cell-Level Autoradiography}

To evaluate the mRNA expression of the PSD proteins at the cellular level, we used high-resolution autoradiographic analysis and silver-grain counting. After exposure to film, we coated hybridized sections with Kodak NTB-2 nuclear emulsion diluted $1: 1$ with sterile water (Kodak). To ensure the consistency of emulsion thickness across sections, we dipped the slides using a Pelco Auto-Dip Emulsion Coater (Ted Pella Inc., Redding, CA), as previously described (Hashimoto et al, 2003). The dipping process was at a constant withdrawal speed $(64 \mathrm{~mm} / \mathrm{min})$ and temperature $\left(43^{\circ} \mathrm{C}\right)$. The sections were air-dried for $3 \mathrm{~h}$ at room temperature and stored in darkness at $4^{\circ} \mathrm{C}$. Test slides were developed at weekly intervals to determine optimal exposure time. After 4-5 weeks, all slides were developed 
in Kodak D19 developer for 2 min, washed in distilled water for $30 \mathrm{~s}$, and fixed in Kodak Rapid Fix for $3 \mathrm{~min}$. Following washing in deionized water for $10 \mathrm{~min}$, the sections were counterstained with thionin, dehydrated in graded alcohols, cleared in xylene, and coverslipped in Permount.

Cellular level autoradiography image analysis. For those PSD proteins for which mRNA expression was changed at the lamina level based on film analysis, we determined if alterations were cell-type specific. Using a Microcomputer Imaging Device system and a Leica DM5000 microscope, we counted silver grains/cell from emulsion-dipped slides by sampling four non-overlapping $220 \times 220 \mu \mathrm{m}$ frames arbitrarily selected from each cortical layer. Cells were identified by counterstaining each section with thionin. As treatment with RNase during in situ hybridization destroys Nissl bodies, it was difficult to draw the contours of the somata of cells, thus we counted grains from each subject by encircling nuclei of 150-200 labeled cortical cells per lamina of four different diameters, depending on the cortical layer where they were located: large cells of layers II, IV, and VI $(18 \mu \mathrm{m})$, large cells of layer III $(22 \mu \mathrm{m})$, large cells of layer $\mathrm{V}$ $(26 \mu \mathrm{m})$, and small cells in all layers $(14 \mu \mathrm{m})$ (Figure 1). These diameters correspond to those previously described in the human prefrontal cortex (Benes et al, 1996). The larger cells include pyramidal neurons in layers II-VI, as well as basket cells (in layers III-VI) and spiny stellate cells (in layer IV), while the smaller cells are a mixture of a number of cell types (bipolar, double bouquet, neurogliaform, Martinotti, and chandelier cells). Most of those smaller cells are GABAergic, except for bipolar cells that are glutamatergic. In the corresponding dark-field image, the software determined the number of silver grains in each circle. The precision of the obtained measurements was given by the software; for all cases we established the threshold of light intensity and size to be considered as positive labeling (silver grains $v s$ dust/artifact), considering positive labeling any number of silver grains above three per cell after subtracting the background. We determined the background value for grain expression for each section by placing circles of the same diameters used for each lamina over underlying white matter, and subtracted that value to get a corrected grains/cell count from each cell. We averaged the corrected number of grains/cell from each circle diameter in each cortical layer from two slides per subject, resulting in two values per cortical layer per subject, one corresponding to large cells $(18,22$, or $26 \mu \mathrm{m})$ and the other to small cells $(14 \mu \mathrm{m})$.

\section{Statistical Analysis}

The dependent variables in the in situ hybridization studies were mRNA concentration for each receptor subunit or PSD protein in each cortical isodense band, for receptor autoradiography was binding in each isodense band, and for cell-level transcript studies was grains/cell. Correlation analysis was carried out to test for associations between post-mortem interval (PMI), age, and $\mathrm{pH}$ and each dependent variable. If significant correlations were found, we used analysis of covariance (ANCOVA) to test the effect of diagnosis. When no significant correlations were found, the effect of diagnosis on each dependent variable was determined by factorial analysis of variance (ANOVA), with diagnosis and isodense band treated as the independent variables for film-level studies, and diagnosis, layer, and cell size as independent variables in cell-level transcript studies. Post hoc analyses were carried out using Tukey's honest significant difference test. Post hoc tests presented in the text contrast individual diagnostic groups with the comparison group. The complete set of comparisons, including between each diagnosis, are presented in Supplementary Table 1, included as Supplementary material. For all tests, $\alpha=0.05$. We used Statistica (Statsoft, Tulsa, OK) software for Windows for all statistical analyses.
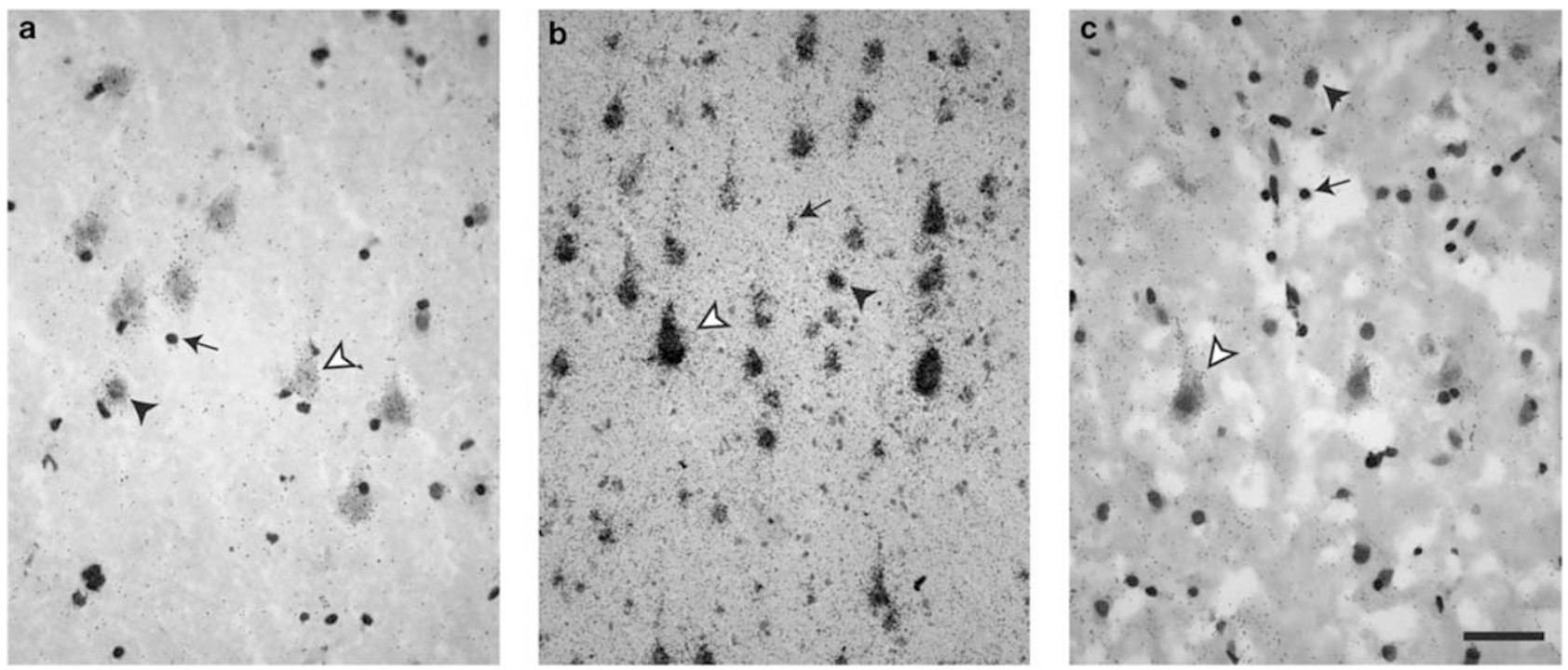

Figure I Bright field photomicrographs of cells in cortical layer III hybridized for PSD95 mRNA (a), NF-L (b), and SAPI 02 (c), showing the distribution of silver grains in large (empty arrowheads) and small cells (black arrowheads), as well as in glial cells (arrows), $\times 40$. Scale bar: $25 \mu$ m. 


\section{RESULTS}

\section{NMDA Receptor Subunits}

In situ hybridization. NMDA subunit mRNA expression was highest for NR1, followed by NR2A and NR2B; NR2C and NR2D were considerably rarer. All NMDA subunits were expressed in a similar laminar pattern, with three isodense bands of relatively higher intensity corresponding to layers II, IV, and VI (Figure 2).

In situ hybridization experiments revealed an association between $\mathrm{pH}$ and the NR1 subunit $(r=0.41, p=0.0009)$ and ANCOVA with $\mathrm{pH}$ as covariate revealed a main effect for diagnosis $(\mathrm{F}=3.7$, d.f. $=3335, p=0.01)$ (Figure 2a). Post hoc analysis showed a significant decrease of NR1 in schizophrenia $(p<0.0001)$, MDD $(p=0.004)$, and BD $(p=0.009)$ (Figure 2f). NR2A was correlated with $\mathrm{pH}$ as well $(r=0.46, p<0.001)$, and ANCOVA revealed a main effect for diagnosis $(\mathrm{F}=3.03$, d.f. $=3335, \quad p=0.03)$
(Figure 2b); post hoc tests revealed decreased expression of NR2A in schizophrenia $(p<0.0001)$ and MDD $(p=0.0002)$ (Figure 2f). Regression analysis for NR2B subunit showed significant association with age $(r=0.3$, $p=0.02)$. ANCOVA indicated a main effect of diagnosis for this subunit $(\mathrm{F}=3.83$, d.f. $=3335, p=0.01)$ that post hoc tests revealed as due to difference between groups (BD $v s$ schizophrenia, $p=0.04$ ) and not compared to control (Figure $2 \mathrm{c}$ and $\mathrm{f}$ ). No associations were found between NR2C expression and $\mathrm{pH}, \mathrm{PMI}$ or age, and ANOVA revealed a main effect of diagnosis $(\mathrm{F}=8.65$, d.f. $=3336, p<0.0001)$ that post hoc testing indicated was due to decreased expression in schizophrenia $(p<0.0001)$ (Figure $2 \mathrm{~d}$ and $\mathrm{f}$ ). Regression analysis for NR2D showed no correlation of the expression of this subunit with age, PMI, or $\mathrm{pH}$. ANOVA indicated a main effect for diagnosis $(\mathrm{F}=2.66$, d.f. $=3336$, $p=0.05$ ) but post hoc analysis did not reveal any significant difference between groups (Figure $2 \mathrm{e}$ and $\mathrm{f}$ ). We did not a

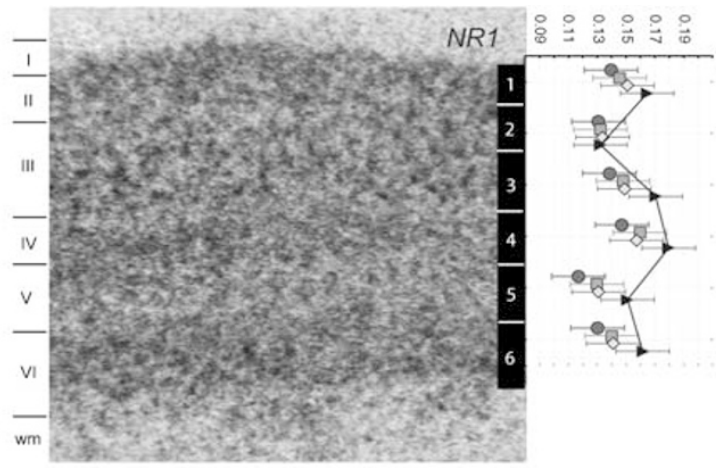

C

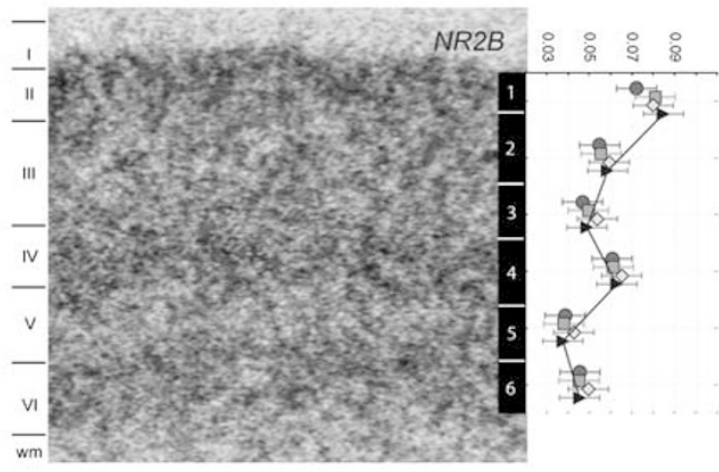

e

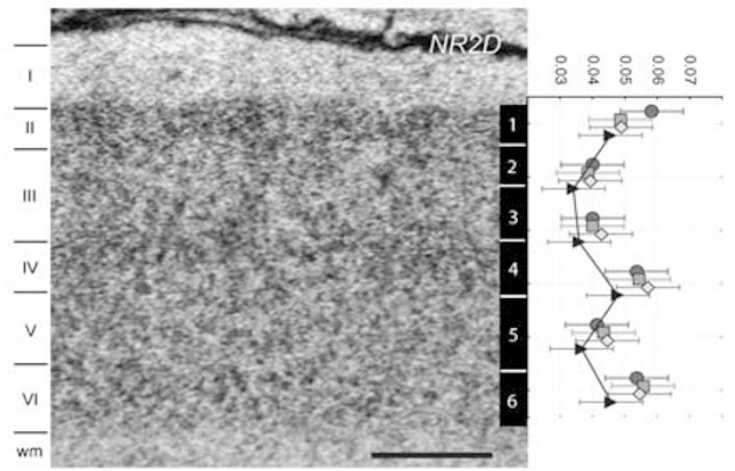

b

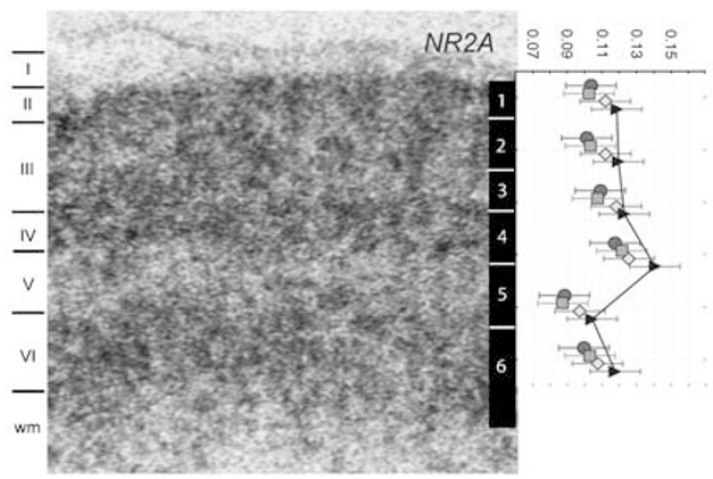

d

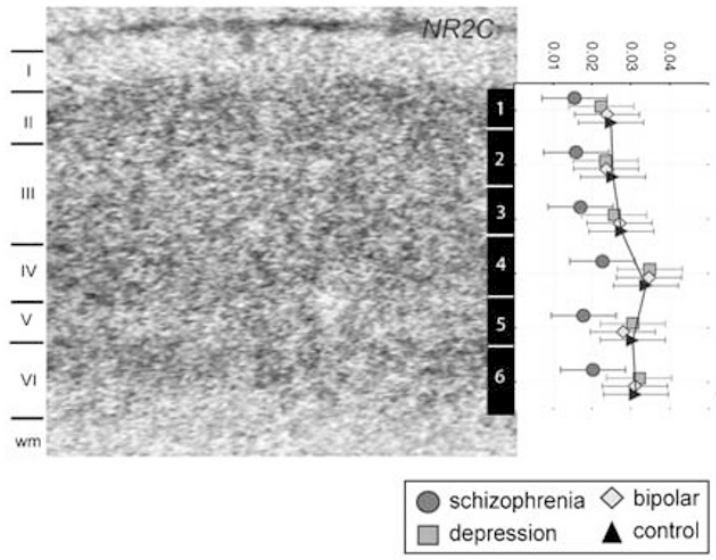

f

\begin{tabular}{|c|c|c|c|c|c|}
\cline { 2 - 6 } \multicolumn{1}{c|}{} & NR1 & NR2A & NR2B & NR2C & NR2D \\
\hline schizophrenia & $\downarrow$ & $\downarrow$ & & $\downarrow$ & \\
\hline $\begin{array}{c}\text { major } \\
\text { depression }\end{array}$ & $\downarrow$ & $\downarrow$ & & & \\
\hline bipolar disorder & $\downarrow$ & & & & \\
\hline
\end{tabular}

Figure 2 Representative in situ hybridization images of transcripts encoding the NMDA receptor subunits in the DLPFC (a-e). The cortical layers for each image are marked in left margin. In the right margin, graphs represent mRNA concentration (fmol/g) in each isodense band for the four subject groups. ( $f$ ) Table showing significant differences from the comparison group $(p<0.05)$. Scale bar: I mm. 
detect diagnosis by isodense band interactions for any of the NMDA subunits.

Receptor-binding autoradiography. Specific binding of the four distinct NMDA-binding sites $\left(\left[{ }^{3} \mathrm{H}\right] \mathrm{MK}-801\right.$ (intrachannel site), $\left[{ }^{3} \mathrm{H}\right]$ ifenprodil (polyamine site), $\left[{ }^{3} \mathrm{H}\right] \mathrm{CGP} 39653$ (glutamate site), and $\left[{ }^{3} \mathrm{H}\right] \mathrm{MDL} 105,519$ (glycine site)) was observed in DLPFC (Figure 3). Receptor autoradiography revealed less complex isodense banding patterns than seen from in situ hybridization studies of subunit transcripts, with binding sites labeled by NMDA radioligands more homogeneously expressed through cortical layers (Figure 3 ). $\left[{ }^{3} \mathrm{H}\right]$ MDL105,519 produced the highest binding density, especially in the infragranular layers (Figure $3 \mathrm{~h}$ ). A slightly different binding pattern was seen for $\left[{ }^{3} \mathrm{H}\right] \mathrm{CGP} 39653$, where a third isodense band corresponding to layers IV-V was noted (Figure 3c). We found no differences by diagnosis in the binding of any of the NMDA ligands (Figure 3).

\section{NMDA Receptor Interacting Proteins}

The NMDA-related PSD proteins PSD95, SAP102, and NF-L were highly expressed throughout the DLPFC (Figure 4). Although expressed across all cortical laminae, all three showed the highest level of expression in layers III and V. Grain-counting analyses indicated that all three transcripts are expressed in both large and small cells (Figure 1), likely pyramidal cells and interneurons, respectively. Some glial cells appeared to express all three transcripts as well (Figure 1).

Multiple regression analysis of PSD95 expression revealed an association with both PMI $(r=0.32, p=0.02)$ and $\mathrm{pH}$ $(r=0.41, p=0.002)$. ANCOVA with both parameters as covariates showed no main effect of diagnosis for expression of PSD95 transcripts. Cell-level grain-counting experiments confirmed the lack of any changes in PSD95 expression (Figure 4a).

There was an association between the expression of NF-L and $\mathrm{pH}(r=0.35 ; p=0.01)$ but not age or PMI. ANCOVA showed a main effect for diagnosis $(\mathrm{F}=5.35$, d.f. $=3244$, $p=0.001)$, and post hoc analysis revealed decreased expression in schizophrenia $(p<0.0001)$ (Figure $4 \mathrm{~b})$. Regression analysis for grains/cell data confirmed the decreased expression of this molecule in schizophrenia compared to controls $(\mathrm{F}=9.03$, d.f. $=1130, p=0.003)$, and was restricted to large cells of layer $\mathrm{V}(p=0.007)$ (Figures $1 b, 5 a$ and $b$ ).

Regression analysis of SAP102 expression showed no associations with $\mathrm{pH}, \mathrm{PMI}$, or age. ANOVA for SAP102 revealed a main effect for diagnosis $(\mathrm{F}=4.78$, d.f. $=3245$, $p=0.003$ ) but no diagnosis by isodense band interaction. Post hoc analysis revealed a decrease in mRNA expression in $\mathrm{BD}(p=0.08)$ compared to controls (Figure 4c). Grain counting in the bipolar group confirmed decreased expression of SAP102 mRNA, but exclusively in the small cells of layer II $(p=0.02)$ and in the large cells of layer III $(p=0.01)$ (Figures $1 c, 5 c$ and $d$ ). a

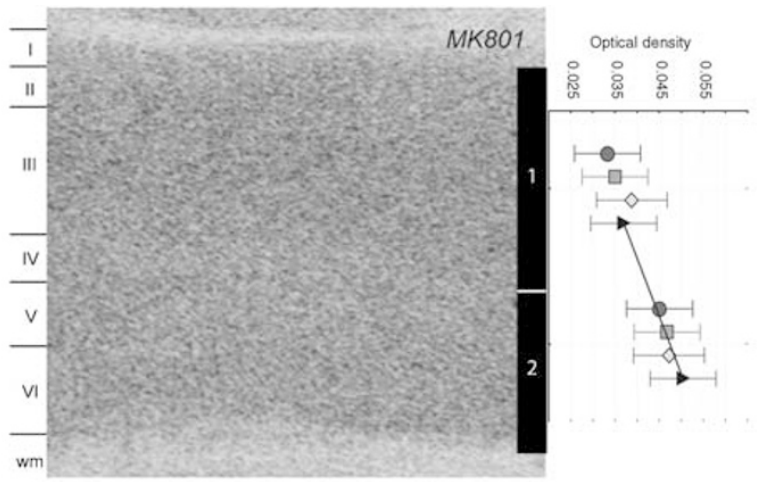

C

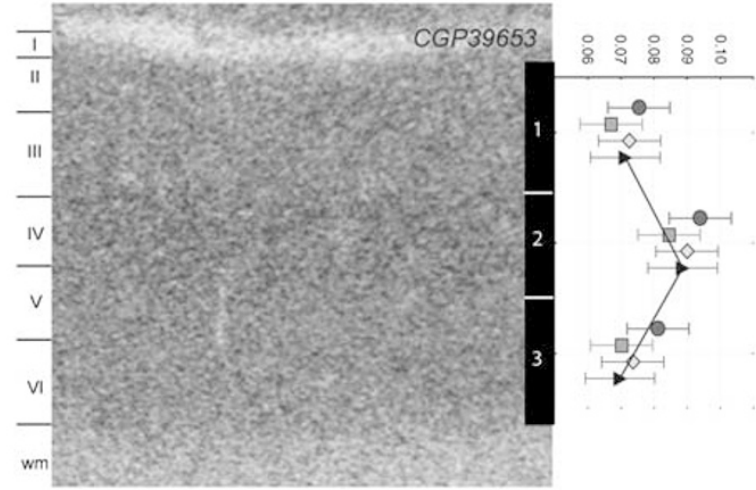

b

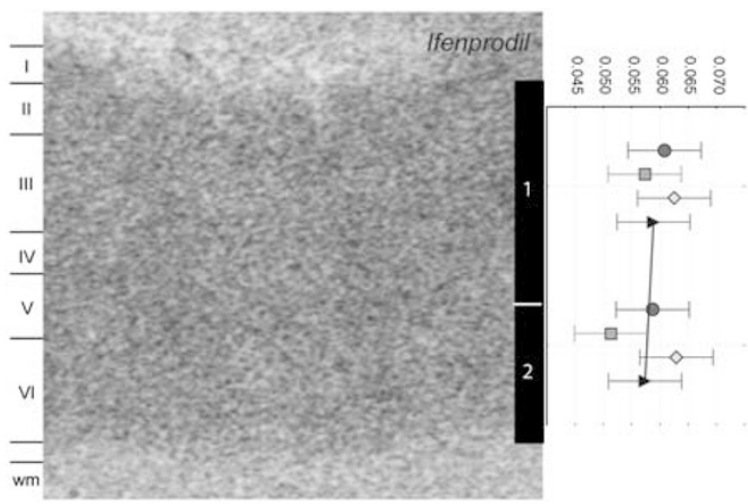

d

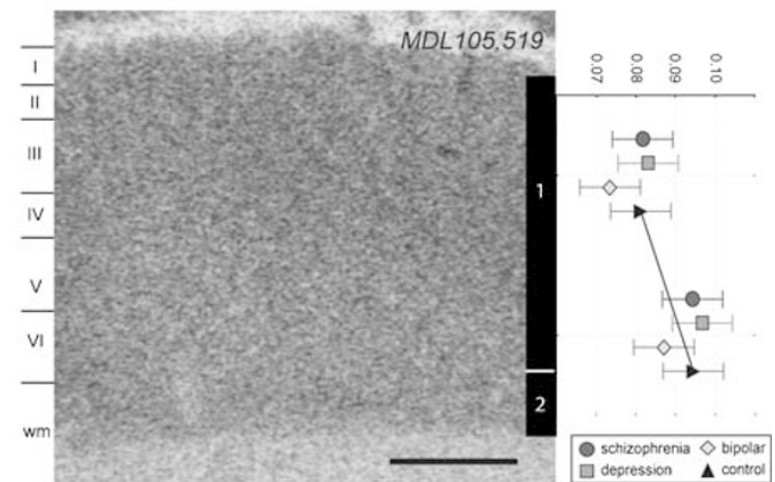

Figure 3 Representative photomicrographs of NMDA receptor-binding autoradiography for (a) $\left[{ }^{3} \mathrm{H}\right] \mathrm{MK} 80 \mathrm{I}$, (b) $\left[{ }^{3} \mathrm{H}\right]$ ifenprodil, (c) $\left[{ }^{3} \mathrm{H}\right] \mathrm{CGP} 39653$, and (d) $\left[^{3} \mathrm{H}\right] \mathrm{MDL}$ 105,5 19. The cortical layers for each image are marked in left margin. In the right margin, graphs represent ligand binding in each isodense band for the four subject groups. No significant differences from the comparison group were found. Scale bar: I mm. 
a

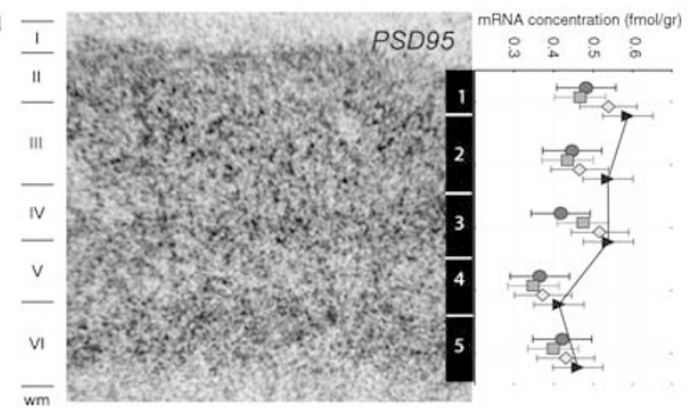

b

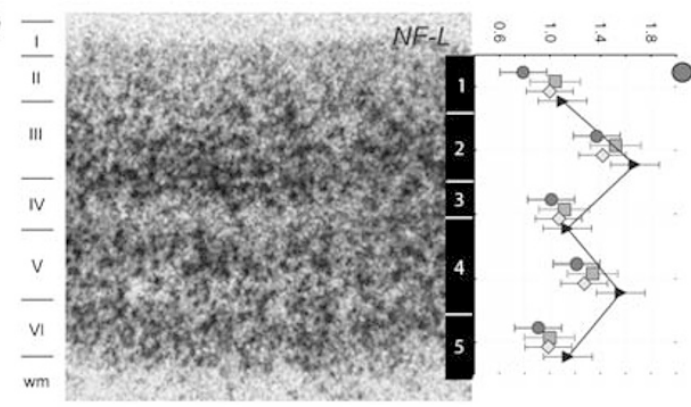

C

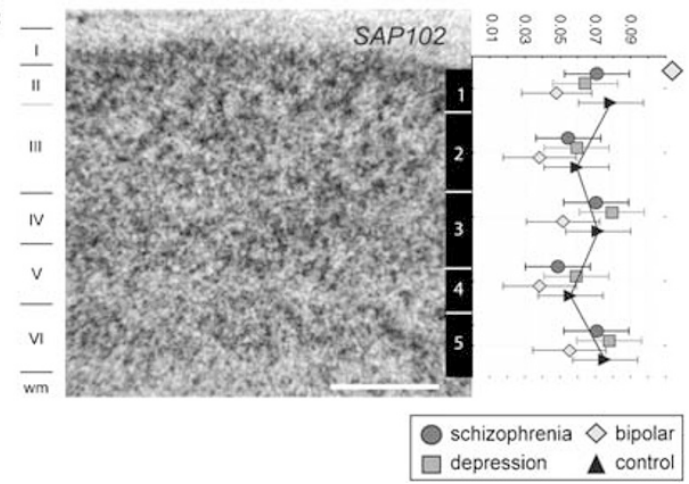

Figure 4 Representative in situ hybridization images of transcripts encoding the NMDA-related postsynaptic density (PSD) proteins. (a) PSD95, (b) NEL, and (c) SAPI02. The cortical layers for each image are marked in the left margin. In the right margin, graphs represent mRNA concentration (fmol/g) in each isodense band for the four subject groups. *Significant differences from the comparison group $(p<0.05)$. SAPI02 was decreased in bipolar subjects, and neurofilament-light (NF-L) in schizophrenia. Scale bar: I mm

We carried out correlation analysis of the expression of the NMDA subunits and their related postsynaptic proteins, often finding positive correlations as for NR1 and NR2A $(p<0.0001)$ and NR2B $(p<0.05)$, and for NR1 and NF-L $(p<0.0001)$ in schizophrenia, as expected by the known interaction pattern of the proteins comprising the NMDA receptor complex.

\section{DISCUSSION}

We found significant changes in the expression of NMDA receptor subunit transcripts in schizophrenia and mood disorders in DLPFC. Some previous publications found no changes in NMDA receptor expression in these illnesses (Kornhuber et al, 1989; Akbarian et al, 1996b).
However, our results are consistent with other reports that have identified significant changes in ionotropic receptors in schizophrenia (Meador-Woodruff et al, 2001a). A shift in the relative proportion of transcripts encoding the NR2 subunits was found in schizophrenia by Akbarian et al (1996a), a finding that correlates with our in situ hybridization results. Using reverse transcriptase polymerase chain reaction (RT-PCR), decreased NR1 mRNA in frontal cortex was found (Sokolov, 1998), while Dracheva et al (2001) found increased expression of NR1 and NR2A but not NR2B transcripts in DLPFC and occipital cortex by RT-PCR. The lack of correspondence between some of our results in schizophrenia and several previous reports of ionotropic receptor expression abnormalities in DLPFC may be due to several factors that could affect mRNA expression. Differences between experimental techniques and subjects characteristics (eg hospitalization status, medication exposure, and age of patients at the time of death) are key factors that may be associated with discrepancies between post-mortem studies.

The abnormal expression of NMDA subunits, together with the lack of changes in receptor binding, suggests a possible change in the stoichiometry of the receptor, which might affect its pharmacology and response to glutamate, as well as its insertion in the postsynaptic membrane. It is interesting that the most robust changes in DLPFC in the three illnesses included in this study involve the 'obligatory' subunit for normal NMDA receptor function, NR1. There is a multitude of cellular mechanisms that regulate the assembly of NMDA receptor subunits into functional channels, endoplasmic reticulum (ER) retention or release, and intracellular trafficking and eventual synaptic delivery (McIlhinney et al, 1998, 2003; Standley et al, 2000; Meddows et al, 2001; Roche et al, 2001; Sans et al, 2001, 2003; Barria and Malinow, 2002, 2005; Wenthold et al, 2003a,b). Demonstration of these effects is found in interesting results from a selective knockout of the NR1 gene, which demonstrated that disrupting NMDA receptor subunit composition impairs normal subcellular targeting of NMDA channels (Fukaya et al, 2003). NR1 deletion in the CA1 hippocampal region leads to retention of the NR2B subunit in the lumen of the ER and accumulation of this subunit in the perikarya. This alteration in ER transit results in reduced expression of the NR2B subunit in NMDA receptors in dendrites (Fukaya et al, 2003).

Alterations of glutamate subunit expression not only can change the electrophysiology of the receptors themselves, but can also change the probability of coupling the receptor to intracellular proteins that mediate many intracellular processes. Pharmacological and post-mortem studies suggest that alterations of glutamatergic neurotransmission occur in schizophrenia and the mood disorders. While this is often assumed to be due to changes in glutamate receptor expression, these alterations might also be a consequence of abnormal protein interactions that could result in misplacement of glutamate receptors in different cellular compartments, lack of stabilization of the receptors in the PSD, abnormal binding to intracellular effector molecules, or dysregulation of receptor turnover. These processes are mediated by, among others, the PSD proteins in the present study. 

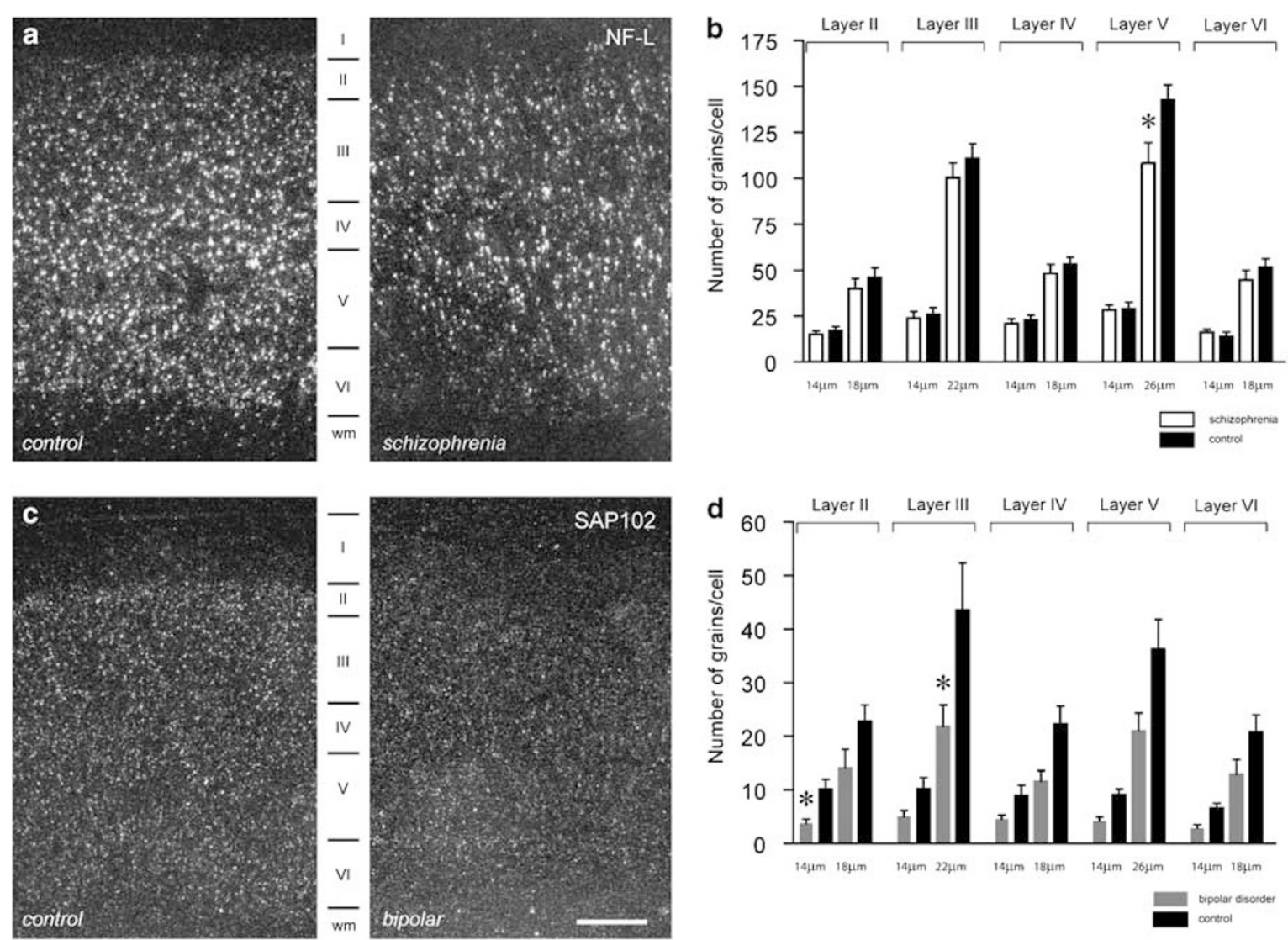

Figure 5 Cellular grain density data for the expression of neurofilament-light (NF-L) in schizophrenia (a and b) and SAPI02 in BD (c and d) and the comparison group. Limits between cortical layers are noted between the photomicrographs (dark field, $\times 2.5)$. Each graph demonstrates grain/cell in both small cells and large cells assayed in each cortical lamina. Diameters of the circles used in each cortical layer are shown. *Significant differences from the comparison group $(p<0.05)$. Scale bar: $500 \mu \mathrm{m}$.

\section{Abnormalities of NMDA-Associated Proteins in Schizophrenia and Mood Disorders}

NMDA receptors are anchored in the postsynaptic membrane and linked to a large complex of intracellular proteins, including PSD95, SAP102, and NF-L. While PSD95 and SAP102 bind exclusively to NR2 subunits, NF$\mathrm{L}$ binds to NR1. In our experiments, we found no changes in PSD95 expression, but decreased transcripts encoding NF-L in schizophrenia and SAP102 in BD. Previous studies have examined PSD95 expression in schizophrenia, and although a previous study found decreased transcript expression in DLPFC (Ohnuma et al, 2000), our results coincide with those that found no changes in PSD95 expression in the cerebral cortex by RT-PCR (Dracheva et al, 2005), immunoautoradiography (Toro and Deakin, 2005), and western blot analysis (Toyooka et al, 2002). Toyooka et al (2002) found decreased SAP102 protein expression in the hippocampus but not DLPFC in schizophrenia. Abnormal SAP102 expression in BD could affect the regulation of NMDA receptor exocytosis in the PSD, as SAP102 is a key protein in the exocyst complex that transports NMDA receptors from the ER to the postsynaptic membrane (Sans et al, 2003).

Previous reports suggest that the intracellular machinery that is coupled to the NMDA receptor subunits is abnormal in BD in the hippocampus (McCullumsmith et al, 2007) and in the thalamus (Clinton and Meador-Woodruff, 2004). Consistent with our results, both studies found decreased expression of transcripts for SAP102 in BD. These data support our results, suggesting that $\mathrm{BD}$ might be associated with abnormalities of glutamate-linked intracellular signaling and trafficking processes.

While PSD95 and SAP102 bind to NR2 subunits, NF-L binds to NR1 and maintains the stability of the NMDA receptor in the PSD by binding actin filaments of the cytoskeleton of the dendritic spine (Ehlers et al, 1995, 1998). This characteristic suggests that decreased NF-L expression in schizophrenia might be part of a more generalized cytoskeletal disruption in the cell as a response to the illness, or alternatively be associated with the decreased expression of this subunit in the same subjects. This suggests a possible instability of NMDA receptors in the postsynaptic membrane that may affect recycling and turnover at the spine, perhaps altering the number of receptors available at the membrane or their clustering at the synapse. Apart from trafficking and stabilizing NMDA receptors at the PSD, NF-L also interacts with protein phosphatase-1 (PP1), an important protein/serine/threonine phosphatase that modulates numerous intracellular pathways (Shenolikar, 1995; Terry-Lorenzo et al, 2000). It has been proposed that NF-L might bind PP1 and position it 
to dephosphorylate other proteins such as CaMKII, actin, or NMDA receptors (Shenolikar, 1995; Terry-Lorenzo et al, 2000), mechanisms that could also be affected by the reduction of NF-L expression we found in schizophrenia. Future examination of posttranslational processes will need to be performed to confirm this hypothesis.

\section{Cellular and Laminar Abnormalities in PSD Proteins Expression}

Our data from cell-level mRNA expression analysis reveal that alterations in NF-L expression in DLPFC in schizophrenia are exclusively located in the large cells of cortical layer V. Histograms of labeled $v s$ nonlabeled cells showed no subpopulation of cells expressing PSD proteins of each cell size (large $v s$ small cells) (data not shown), patterns shown for some other proteins in the prefrontal cortex (Hashimoto et al, 2005) and striatum (Gerfen et al, 1991). This suggests that the vast majority of cells in which we saw differences in PSD protein expression are pyramidal cells of layers III and V. Thalamocortical input to the pyramidal cells of the DLPFC almost exclusively innervate layer IV, but those terminals have been shown to make synaptic contact with the apical dendrites of the pyramidal cells of layer $\mathrm{V}$ (Staiger et al, 2004). Interestingly, layer $\mathrm{V}$ receive also modest projections from the spiny stellate cells of layer IV, where most thalamocortical afferents are located. Recent studies have shown that layer-IV spiny neurons form a highly interconnected local excitatory network that is able to amplify weak thalamic input before it is relayed to the supragranular layers (Stratford et al, 1996; Feldmeyer et al, 1999, 2002). Our results suggest a dysregulation of the expression of the molecules implicated in glutamatergic signaling in layer $\mathrm{V}$ in schizophrenia. This may produce abnormal reception of thalamocortical and layer-III and -IV synapses, affecting afferent cortical and subcortical circuits.

In $\mathrm{BD}$ we detected decreased expression of SAP102, exclusively in small cells of layer II and large cells of layer III of the DLPFC. Abnormal neurotransmission in projecting layer-III cells would have an effect on their ipsi- and contralateral projections to layers II and III, and locally to the apical dendrites of the pyramidal cells of layer $\mathrm{V}$, while dysfunction of small layer-II cells, probably interneurons, would result in abnormalities in signal transmission modulation of inputs from layer III to layer II pyramidal cells and their subsequent corticocortical connections to other areas.

Our finding of expression of NMDA receptor-related intracellular proteins in glial cells require special mention. Aside from their important role in removing glutamate from the extracellular medium, astrocytes have been shown to respond to glutamate via activation of specific receptors. Using pharmacological and molecular approaches, astroglial expression of AMPA and kainate receptors is established (Burnashev et al, 1992; Condorelli et al, 1993, 1999; Jabs et al, 1994; Seifert and Steinhauser, 1995; Seifert et al, 1997; Verkhratsky and Steinhauser, 2000; Burnashev, 2005) and functional NMDA receptor expression in astrocytes has been demonstrated recently. Analysis of the functional expression of NMDA receptors in astrocytes revealed significant differences from neuronal NMDA receptors (Schipke et al, 2001). Subunits of NMDA receptors have been detected in astrocytes by immunohistochemistry, in situ hybridization, and PCR (Schipke et al, 2001). Several functional studies have demonstrated NMDA-mediated currents and NMDA-induced $\left[\mathrm{Ca}^{2+}\right]$ responses in astrocytes (Shao and McCarthy, 1997; Ziak et al, 1998; Kondoh et al, 2001; Schipke et al, 2001). Recordings from astrocytes in slices revealed slow currents (Schipke et al, 2001), which did not resemble classic NMDA receptor-mediated responses (Lalo et al, 2006; Verkhratsky and Kirchhoff, 2007). In a very elegant study, Lalo et al (2006) identified NMDA-induced currents in cortical astrocytes, and showed that these currents can also be activated by glutamate released after stimulation of neuronal synaptic terminals as well as during spontaneous release of neurotransmitter. Our results showing expression of NMDA receptor-associated intracellular proteins further support the existence of functional NMDA receptors in cortical astrocytes.

\section{LIMITATIONS OF THE STUDY}

The direct study of the post-mortem human brain is critical in the study of psychiatric disorders, but also has important limitations. For example, markers of the quality of mRNA need to be considered. In our case, we often found significant correlations between PMI, brain $\mathrm{pH}$, or age of the subjects, and the expression of the molecules studied. It has been shown that the impact of PMI on mRNA integrity in post-mortem studies is secondary to agonal status and freezing of the tissue (Harrison et al, 1995, 1991; Kingsbury et al, 1995; Yates et al, 1990). In this study, PMI was correlated with the expression of several of the molecules studied, and in those cases we used PMI as a covariate in the data analysis.

Although enzyme-activity measures can be affected by brain pH (Yates et al, 1990; Taylor et al, 1986; Perry et al, 1982), immunoreactivity of brain proteins and ligand binding to receptors do not appear to vary substantially as a function of brain $\mathrm{pH}$ (Harrison et al, 1995). However, tissue levels of many mRNAs can be related to brain $\mathrm{pH}$ (Harrison et al, 1995; Kingsbury et al, 1995). Based on observations that sudden deaths are associated with brain $\mathrm{pH}$ of $\sim 6.8$ and prolonged agonal states may produce a brain $\mathrm{pH}$ of $<6.0$, Harrison and Kleinman (2000) have recommended that all brains be screened for $\mathrm{pH}$ and those with values $<6.1$ be excluded from study, a recommendation that we followed in this study.

Age has been shown to be an important factor in glutamate receptor binding and mRNA expression in rodents (Magnusson, 1998, 2000; Nicolle and Baxter, 2003). We found no significant correlations with age and NMDA binding of any of the ligands we used in this study, and except for NR2B, no associations with NMDA subunit expression and age.

In conclusion, our data suggest that both schizophrenia and $\mathrm{BD}$ are characterized by alterations in the transcript expression of subunits of the NMDA receptor, as well as associated intracellular proteins in the DLPFC in both illnesses. The identification of the abnormal expression of these molecules related to glutamate receptor trafficking and signaling provides evidence for the involvement of the 
glutamate system in the pathophysiology of schizophrenia and mood disorders.

\section{ACKNOWLEDGEMENTS}

This study was supported by Grant MH53327 ( to JHM-W). We gratefully acknowledge the technical assistance of Scott Polewach and Gabriel D Velasquez. Post-mortem brains were donated by The Stanley Medical Research Institute's Brain Collection courtesy of Drs Michael B Knable, E Fuller Torrey, Maree J Webster, Serge Weis, and Robert H Yolken.

\section{DISCLOSURE/CONFLICT OF INTEREST}

$\mathrm{JH}$ Meador-Woodruff is the editor-in-chief of this journal and receives an honorarium from ACNP; he has no other conflicts of interest. Dr Beneyto has no conflicts of interests.

\section{REFERENCES}

Akbarian S, Sucher NJ, Bradley D, Tafazzoli A, Trinh D, Hetrick WP et al (1996a). Selective alterations in gene expression for NMDA receptor subunits in prefrontal cortex of schizophrenics. J Neurosci 16: 19-30.

Akbarian S, Sucher NJ, Bradley D, Tafazzoli A, Trinh D, Hetrick WP et al (1996b). Selective alterations in gene expression for NMDA receptor subunits in prefrontal cortex of schizophrenics. J Neurosci 16: 19-30.

Baron BM, Siegel BW, Harrison BL, Gross RS, Hawes C, Towers P (1996). [3H]MDL 105,519, a high-affinity radioligand for the $\mathrm{N}$ methyl-D-aspartate receptor-associated glycine recognition site. $J$ Pharmacol Exp Ther 279: 62-68.

Barria A, Malinow R (2002). Subunit-specific NMDA receptor trafficking to synapses. Neuron 35: 345-353.

Barria A, Malinow R (2005). NMDA receptor subunit composition controls synaptic plasticity by regulating binding to CaMKII. Neuron 48: 289-301.

Belsham B (2001a). Glutamate and its role in psychiatric illness. Hum Psychopharmacol 16: 139-146.

Belsham B (2001b). Glutamate and its role in psychiatric illness. Hum Psychopharmacol 16: 139-146.

Benes FM, Vincent SL, Marie A, Khan Y (1996). Up-regulation of GABAA receptor binding on neurons of the prefrontal cortex in schizophrenic subjects. Neuroscience 75: 1021-1031.

Braff DL, Swerdlow NR, Geyer MA (1999). Symptom correlates of prepulse inhibition deficits in male schizophrenic patients. Am J Psychiatry 156: 596-602.

Burnashev N (2005). Dynamic modulation of AMPA receptormediated synaptic transmission by polyamines in principal neurons. Focus on 'polyamines modulate AMPA receptordependent synaptic response in immature layer $v$ pyramidal neurons'. J Neurophysiol 93: 2371.

Burnashev N, Khodorova A, Jonas P, Helm PJ, Wisden W, Monyer H. et al (1992). Calcium-permeable AMPA-kainate receptors in fusiform cerebellar glial cells. Science 256: 1566-1570.

Clinton SM, Meador-Woodruff JH (2004). Abnormalities of the NMDA receptor and associated intracellular molecules in the thalamus in schizophrenia and bipolar disorder. Neuropsychopharmacology 29: 1353-1362.

Condorelli DF, Conti F, Gallo V, Kirchhoff F, Seifert G, Steinhauser $C$ et al (1999). Expression and functional analysis of glutamate receptors in glial cells. Adv Exp Med Biol 468: 49-67.

Condorelli DF, Dell'Albani P, Corsaro M, Barresi V, Giuffrida Stella AM (1993). AMPA-selective glutamate receptor subunits in astroglial cultures. J Neurosci Res 36: 344-356.
Craven SE, Bredt DS (1998). PDZ proteins organize synaptic signaling pathways. Cell 93: 495-498.

Dracheva S, Marras SA, Elhakem SL, Kramer FR, Davis KL, Haroutunian V (2001). N-methyl-D-aspartic acid receptor expression in the dorsolateral prefrontal cortex of elderly patients with schizophrenia. Am J Psychiatry 158: 1400-1410.

Dracheva S, McGurk SR, Haroutunian V (2005). mRNA expression of AMPA receptors and AMPA receptor binding proteins in the cerebral cortex of elderly schizophrenics. J Neurosci Res 79: 868878.

Du J, Gray NA, Falke CA, Chen W, Yuan P, Szabo ST et al (2004). Modulation of synaptic plasticity by antimanic agents: the role of AMPA glutamate receptor subunit 1 synaptic expression. $J$ Neurosci 24: 6578-6589.

Duncan GE, Moy SS, Lieberman JA, Koller BH (2006). Effects of haloperidol, clozapine, and quetiapine on sensorimotor gating in a genetic model of reduced NMDA receptor function. Psychopharmacology (Berl) 184: 190-200.

Duncan GE, Moy SS, Perez A, Eddy DM, Zinzow WM, Lieberman JA et al (2004). Deficits in sensorimotor gating and tests of social behavior in a genetic model of reduced NMDA receptor function. Behav Brain Res 153: 507-519.

Ehlers M, Fung E, O’Brien R, Huganir R (1998). Splice variantspecific interaction of the NMDA receptor subunit NR1 with neuronal intermediate filaments. J Neurosci 18: 720-730.

Ehlers MD, Tingley WG, Huganir RL (1995). Regulated subcellular distribution of the NR1 subunit of the NMDA receptor. Science 269: 1734-1737.

Feldmeyer D, Egger V, Lubke J, Sakmann B (1999). Reliable synaptic connections between pairs of excitatory layer 4 neurones within a single 'barrel' of developing rat somatosensory cortex. J Physiol 521(Part 1): 169-190.

Feldmeyer D, Lubke J, Silver RA, Sakmann B (2002). Synaptic connections between layer 4 spiny neurone-layer $2 / 3$ pyramidal cell pairs in juvenile rat barrel cortex: physiology and anatomy of interlaminar signalling within a cortical column. J Physiol 538: 803-822.

Fukaya M, Kato A, Lovett C, Tonegawa S, Watanabe M (2003). Retention of NMDA receptor NR2 subunits in the lumen of endoplasmic reticulum in targeted NR1 knockout mice. Proc Natl Acad Sci USA 100: 4855-4860.

Garner CC, Nash J, Huganir RL (2000). PDZ domains in synapse assembly and signalling. Trends Cell Biol 10: 274-280.

Gerfen CR, McGinty JF, Young III WS (1991). Dopamine differentially regulates dynorphin, substance $P$, and enkephalin expression in striatal neurons: in situ hybridization histochemical analysis. J Neurosci 11: 1016-1031.

Geyer MA, Braff DL (1987). Startle habituation and sensorimotor gating in schizophrenia and related animal models. Schizophr Bull 13: 643-668.

Grillon C, Ameli R, Charney DS, Krystal J, Braff D (1992). Startle gating deficits occur across prepulse intensities in schizophrenic patients. Biol Psychiatry 32: 939-943.

Harrison PJ, Heath PR, Eastwood SL, Burnet PW, McDonald B, Pearson RC (1995). The relative importance of premortem acidosis and postmortem interval for human brain gene expression studies: selective mRNA vulnerability and comparison with their encoded proteins. Neurosci Lett 200: 151-154.

Harrison PJ, Kleinman JE (2000). Methodological issues. In: Harrison PJ, Roberts GW (eds). The Neuropathology of Schizophrenia. Oxford University Press: New York, pp 339-350.

Harrison PJ, Procter AW, Barton AJ, Lowe SL, Najlerahim A, Bertolucci PH et al (1991). Terminal coma affects messenger RNA detection in post mortem human temporal cortex. Brain Res Mol Brain Res 9: 161-164.

Hashimoto K, Mantione CR, Spada MR, Neumeyer JL, London ED (1994). Further characterization of [3H]ifenprodil binding in rat brain. Eur J Pharmacol 266: 67-77. 
Hashimoto T, Volk DW, Eggan SM, Mirnics K, Pierri JN, Sun Z et al (2003). Gene expression deficits in a subclass of GABA neurons in the prefrontal cortex of subjects with schizophrenia. $J$ Neurosci 23: 6315-6326.

Hashimoto T, Arion G, Unger T, Volk DW, Mirnics K, Lewis DA (2005). Analysis of gaba-specific transcriptome in the prefrontal cortex of subjects with schizophrenia. Soc Neurosci Abstr 35, 675.4 .

Healy DJ, Haroutunian V, Powchik P, Davidson M, Davis KL, Watson SJ et al (1998). AMPA receptor binding and subunit mRNA expression in prefrontal cortex and striatum of elderly schizophrenics. Neuropsychopharmacology 19: 278-286.

Healy DJ, Meador-Woodruff JH (1999). Ionotropic glutamate receptor modulation of 5-HT6 and 5-HT7 mRNA expression in rat brain. Neuropsychopharmacology 21: 341-351.

Hertzmann M, Reba RC, Kotlyarov EV (1990). Single photon emission computed tomography in phencyclidine and related drug abuse. Am J Psychiatry 147: 255-256.

Hsueh YP, Sheng M (1998). Anchoring of glutamate receptors at the synapse. Prog Brain Res 116: 123-131.

Huettner JE, Bean BP (1988). Block of $N$-methyl-D-aspartateactivated current by the anticonvulsant MK-801: selective binding to open channels. Proc Natl Acad Sci USA 85: 1307-1311.

Ibrahim H, Healy D, Hogg AJ, Meador-Woodruff J (2000a). Nucleus-specific expression of ionotropic glutamate receptor subunit mRNAs and binding sites in primate thalamus. Brain Res Mol Brain Res 79: 1-17.

Ibrahim HM, Hogg Jr AJ, Healy DJ, Haroutunian V, Davis KL, Meador-Woodruff JH (2000b). Ionotropic glutamate receptor binding and subunit mRNA expression in thalamic nuclei in schizophrenia. Am J Psychiatry 157: 1811-1823.

Jabs R, Kirchhoff F, Kettenmann H, Steinhauser C (1994). Kainate activates $\mathrm{Ca}(2+)$-permeable glutamate receptors and blocks voltage-gated $\mathrm{K}+$ currents in glial cells of mouse hippocampal slices. Pflugers Arch 426: 310-319.

Kennedy MB (1997). The postsynaptic density at glutamatergic synapses. Trends Neurosci 20: 264-268.

Kingsbury AE, Foster OJ, Nisbet AP, Cairns N, Bray L, Eve DJ et al (1995). Tissue $\mathrm{pH}$ as an indicator of mRNA preservation in human post-mortem brain. Brain Res Mol Brain Res 28: 311-318.

Kondoh T, Nishizaki T, Aihara H, Tamaki N (2001). NMDAresponsible, APV-insensitive receptor in cultured human astrocytes. Life Sci 68: 1761-1767.

Kornhuber J, Mack-Burkhardt F, Riederer P, Hebenstreit GF, Reynolds GP, Andrews HB et al (1989). [3H]MK-801 binding sites in postmortem brain regions of schizophrenic patients. $J$ Neural Transm 77: 231-236.

Lalo U, Pankratov Y, Kirchhoff F, North RA, Verkhratsky A (2006). NMDA receptors mediate neuron-to-glia signaling in mouse cortical astrocytes. J Neurosci 26: 2673-2683.

Magnusson KR (1998). Aging of glutamate receptors: correlations between binding and spatial memory performance in mice. Mech Ageing Dev 104: 227-248.

Magnusson KR (2000). Declines in mRNA expression of different subunits may account for differential effects of aging on agonist and antagonist binding to the NMDA receptor. J Neurosci 20: 1666-1674.

McCullumsmith RE, Clinton SM, Meador-Woodruff JH (2004). Schizophrenia as a disorder of neuroplasticity. Int Rev Neurobiol 59: $19-45$.

McCullumsmith RE, Meador-Woodruff JH (2002). Striatal excitatory amino acid transporter transcript expression in schizophrenia, bipolar disorder, and major depressive disorder. Neuropsychopharmacology 26: 368-375.

McCullumsmith RE, Kristiansen LV, Beneyto M, Scarr E, Dean B, Meador-Woodruff JH (2007). Decreased NRI, NR2A, and SAP102 transcript expression in the hippocampus in bipolar disorder. Brain Res 1127: 108-118.
McDowd JM, Filion DL, Harris MJ, Braff DL (1993). Sensory gating and inhibitory function in late-life schizophrenia. Schizophr Bull 19: 733-746.

McIlhinney RA, Le Bourdelles B, Molnar E, Tricaud N, Streit P, Whiting PJ (1998). Assembly intracellular targeting and cell surface expression of the human $N$-methyl-D-aspartate receptor subunits NR1a and NR2A in transfected cells. Neuropharmacology 37: 1355-1367.

McIlhinney RA, Philipps E, Le Bourdelles B, Grimwood S, Wafford $\mathrm{K}$, Sandhu S. et al (2003). Assembly of $N$-methyl-D-aspartate (NMDA) receptors. Biochem Soc Trans 31: 865-868.

Meador-Woodruff JH, Davis KL, Haroutunian V (2001a). Abnormal kainate receptor expression in prefrontal cortex in schizophrenia. Neuropsychopharmacology 24: 545-552.

Meador-Woodruff JH, Hogg Jr AJ, Smith RE (2001b). Striatal ionotropic glutamate receptor expression in schizophrenia, bipolar disorder, and major depressive disorder. Brain Res Bull 55: 631-640.

Meddows E, Le Bourdelles B, Grimwood S, Wafford K, Sandhu S, Whiting $\mathrm{P}$ et al (2001). Identification of molecular determinants that are important in the assembly of $N$-methyl-D-aspartate receptors. J Biol Chem 276: 18795-18803.

Miller JA (1991). The calibration of 35S or 32P with 14C-labeled brain paste or 14C-plastic standards for quantitative autoradiography using LKB Ultrofilm or Amersham Hyperfilm. Neurosci Lett 121: 211-214.

Molnar M, Potkin SG, Bunney WE, Jones EG (2003). MRNA expression patterns and distribution of white matter neurons in dorsolateral prefrontal cortex of depressed patients differ from those in schizophrenia patients. Biol Psychiatry 53: 39-47.

Moy SS, Perez A, Koller BH, Duncan GE (2006). Amphetamineinduced disruption of prepulse inhibition in mice with reduced NMDA receptor function. Brain Res 1089: 186-194.

Mueller HT, Meador-Woodruff JH (2004). NR3A NMDA receptor subunit mRNA expression in schizophrenia, depression and bipolar disorder. Schizophr Res 71: 361-370.

Nicolle MM, Baxter MG (2003). Glutamate receptor binding in the frontal cortex and dorsal striatum of aged rats with impaired attentional set-shifting. Eur J Neurosci 18: 3335-3342.

Ohnuma T, Kato H, Arai H, Faull R, McKenna P, Emson P (2000). Gene expression of PSD95 in prefrontal cortex and hippocampus in schizophrenia. Neuroreport 11: 3133-3137.

Perry EK, Perry RH, Tomlinson BE (1982). The influence of agonal status on some neurochemical activities of postmortem human brain tissue. Neurosci Lett 29: 303-307.

Ransom RW, Stec NL (1988). Cooperative modulation of [3H]MK801 binding to the $N$-methyl-D-aspartate receptor-ion channel complex by L-glutamate, glycine, and polyamines. J Neurochem 51: $830-836$

Roche KW, Standley S, McCallum J, Dune Ly C, Ehlers MD, Wenthold RJ (2001). Molecular determinants of NMDA receptor internalization. Nat Neurosci 4: 794-802.

Sans N, Prybylowski K, Petralia RS, Chang K, Wang YX, Racca C et al (2003). NMDA receptor trafficking through an interaction between PDZ proteins and the exocyst complex. Nat Cell Biol 5: 520-530.

Sans N, Racca C, Petralia RS, Wang YX, McCallum J, Wenthold RJ (2001). Synapse-associated protein 97 selectively associates with a subset of AMPA receptors early in their biosynthetic pathway. $J$ Neurosci 21: 7506-7516.

Schipke CG, Ohlemeyer C, Matyash M, Nolte C, Kettenmann H, Kirchhoff F (2001). Astrocytes of the mouse neocortex express functional $N$-methyl-D-aspartate receptors. FASEB $J$ 15: $1270-1272$.

Seifert G, Rehn L, Weber M, Steinhauser C (1997). AMPA receptor subunits expressed by single astrocytes in the juvenile mouse hippocampus. Brain Res Mol Brain Res 47: 286-294. 
Seifert G, Steinhauser C (1995). Glial cells in the mouse hippocampus express AMPA receptors with an intermediate Ca2+ permeability. Eur J Neurosci 7: 1872-1881.

Shao Y, McCarthy KD (1997). Responses of Bergmann glia and granule neurons in situ to $N$-methyl-D-aspartate, norepinephrine, and high potassium. J Neurochem 68: 2405-2411.

Shenolikar S (1995). Protein phosphatase regulation by endogenous inhibitors. Semin Cancer Biol 6: 219-227.

Shoemaker JM, Saint Marie RL, Bongiovanni MJ, Neary AC, Tochen LS, Swerdlow NR (2005). Prefrontal D1 and ventral hippocampal $N$-methyl-D-aspartate regulation of startle gating in rats. Neuroscience 135: 385-394.

Siegel BW, Sreekrishna K, Baron BM (1996). Binding of the radiolabeled glycine site antagonist [3H]MDL 105,519 to homomeric NMDA-NR1a receptors. Eur J Pharmacol 312: 357365.

Sills MA, Fagg G, Pozza M, Angst C, Brundish DE, Hurt SD et al (1991). [3H]CGP 39653: a new $N$-methyl-D-aspartate antagonist radioligand with low nanomolar affinity in rat brain. Eur $J$ Pharmacol 192: 19-24.

Sokolov BP (1998). Expression of NMDAR1, GluR1, GluR7, and KA1 glutamate receptor mRNAs is decreased in frontal cortex of 'neuroleptic-free' schizophrenics: evidence on reversible up-regulation by typical neuroleptics. J Neurochem 71: 2454-2464.

Staiger JF, Flagmeyer I, Schubert D, Zilles K, Kotter R, Luhmann HJ (2004). Functional diversity of layer IV spiny neurons in rat somatosensory cortex: quantitative morphology of electrophysiologically characterized and biocytin labeled cells. Cereb Cortex 14: 690-701.

Standley S, Roche KW, McCallum J, Sans N, Wenthold RJ (2000). PDZ domain suppression of an ER retention signal in NMDA receptor NR1 splice variants. Neuron 28: 887-898.

Stratford KJ, Tarczy-Hornoch K, Martin KA, Bannister NJ, Jack JJ (1996). Excitatory synaptic inputs to spiny stellate cells in cat visual cortex. Nature 382: 258-261.

Taylor GR, Carter GI, Crow TJ, Johnson JA, Fairbairn AF, Perry EK et al (1986). Recovery and measurement of specific RNA species from postmortem brain tissue: a general reduction in Alzheimer's disease detected by molecular hybridization. Exp Mol Pathol 44: 111-116.
Terry-Lorenzo RT, Inoue M, Connor JH, Haystead TA, Armbruster BN, Gupta RP et al (2000). Neurofilament-L is a protein phosphatase-1-binding protein associated with neuronal plasma membrane and post-synaptic density. J Biol Chem 275: 24392446.

Toro C, Deakin JF (2005). NMDA receptor subunit NRI and postsynaptic protein PSD-95 in hippocampus and orbitofrontal cortex in schizophrenia and mood disorder. Schizophr Res 80: 323-330.

Torrey EF, Webster M, Knable M, Johnston N, Yolken RH (2000). The Stanley Foundation brain collection and neuropathology consortium. Schizophr Res 44: 151-155.

Toyooka K, Iritani S, Makifuchi T, Shirakawa O, Kitamura N, Maeda $\mathrm{K}$ et al (2002). Selective reduction of a PDZ protein, SAP97 , in the prefrontal cortex of patients with chronic schizophrenia. J Neurochem 83: 797-806.

Verkhratsky A, Kirchhoff F (2007). NMDA receptors in glia. Neuroscientist 13: 28-37.

Verkhratsky A, Steinhauser C (2000). Ion channels in glial cells. Brain Res Brain Res Rev 32: 380-412.

Wenthold RJ, Prybylowski K, Standley S, Sans N, Petralia RS (2003a). Trafficking of NMDA receptors. Annu Rev Pharmacol Toxicol 43: 335-358.

Wenthold RJ, Sans N, Standley S, Prybylowski K, Petralia RS (2003b). Early events in the trafficking of $N$-methyl-D-aspartate (NMDA) receptors. Biochem Soc Trans 31: 885-888.

White BH, Vogel MW (1996). CGP 39653 binding in the chick CNS after NMDA receptor antagonist treatment. J Neural Transm 103: 1247-1253.

Woo TU, Walsh JP, Benes FM (2004). Density of glutamic acid decarboxylase 67 messenger RNA-containing neurons that express the $\mathrm{N}$-methyl-D-aspartate receptor subunit NR2A in the anterior cingulate cortex in schizophrenia and bipolar disorder. Arch Gen Psychiatry 61: 649-657.

Yates CM, Butterworth J, Tennant MC, Gordon A (1990). Enzyme activities in relation to $\mathrm{pH}$ and lactate in postmortem brain in Alzheimer-type and other dementias. J Neurochem 55: 16241630.

Ziak D, Chvatal A, Sykova E (1998). Glutamate-, kainate- and NMDA-evoked membrane currents in identified glial cells in rat spinal cord slice. Physiol Res 47: 365-375.

Supplementary Information accompanies the paper on the Neuropsychopharmacology website (http://www.nature.com/npp) 